\title{
СТРУКТУРНО-ЛІНГВІСТИЧНА МОДЕЛЬ ОПИСУ НАДІЙНОСТІ ОПЕРАТОРСЬКОї ДІЯЛЬНОСТІ
}

\author{
В. В. Кальниш ${ }^{1}$, А. В. Швець² \\ Інститут медицини праці НАМН України \\ НДІ проблем військової медицини ЗС України²
}

\begin{abstract}
In article the original approach for operators' activity reliability research using methods of the structurally-linguistic analysis that allow to receive the additional information concerning formation of operator's chronoalgorithm behavioral reactions under different intensity of information processing and rising a fatigue level has been offered. It has been analyzed seven types of incorrect human reactions using characteristics of their "uniqueness", "variety" and "generality". The relation of this errors' typology from fatigue level and information overloading has been established. The randomness increasing in actions both with fatigue increasing can lead to occurrence of absolutely unpredictable situations at the occupational activity realization by operator and decrease the freedom degrees in decision-making at time deficiency conditions has been revealed.
\end{abstract}

Зпозицій структурноїлінгвістики, в основі надійності системи «людина-машина» лежить особливість переробки інформації, що обумовлена обмеженістю як інтелектуальних ресурсів людського організму (зокрема мозку), так і виникаючих в результаті професійної діяльності сценаріїв. В силу обмеженості своїх ресурсів, будь-яка інтелектуальна система змушена все спрощувати (“узагальнювати”), вишукувати вже відомі явища або їх частини (образи), приводячи тим самим цю інформацію до раніше знайденого виду, “зручного” для зберігання і “дешифрування”. При цьому вона знаходить “зміст” і “образ” там, де його, можливо, і немає. Такий процес постійного перетворення системою інформації призводить до вироблення певного сценарію її взаємодії з середовищем. В багатьох публікаціях нами було здійснено спробу застосувати структурно-лінгвістичний підхід для характеристики надійності професійної діяльності. Так, проаналізовано особливості типології помилкових реакцій в гендерному аспекті, в інших публікаціях було здійснено оцінку надійності професійної діяльності 3 використанням логістичного аналізу. Показано також необхідність врахування не тільки інформаційної, але й енергетичної складової організму для прогнозування надійності професійної діяльності психофізіологічними засобами. Однак, детальної характеристики появи різних типів помилкових реакцій як умовної «мови» взаємодії людини 3 машиною протягом тривалого часу (доби) в умовах виконання професійної діяльності проведено не було.

Тому метою роботи є застосування структурнолінгвістичної моделі для характеристики особливостей появи різних типів помилок в операторів.

Матеріали та методи досліджень. У якості об'єкта досліджень була обрана група чоловіків опера- торів-радіотелеграфістів (32 особи) віком 18-23 роки, які виконували професійні обов' язки - операторську діяльність - безперервно протягом доби. Психофізіологічні характеристики реєстрували 3 допомогою спеціального апаратно-програмного комплексу, який був розроблений в Харківському національному університеті радіоелектроніки. Стан ЦНС визначали за показниками функціональної рухливості нервових процесів (ФРНП, мс) при дії зорових сигналів різної модальності. Діагностування ФРНП здійснено за модифікованою методикою М. В. Макаренка, реалізованою зі зворотним зв'язком.

Дослідження стану ЦНС цих осіб проводили в ранковий час (з $8^{00}$ до $9^{00}$ години) до заступання на добове чергування та безпосередньо після нього. 3 допомогою кластерного аналізу було виділено 2 підгрупи осіб з різними величинами зміни працездатності після добового чергування. Першу підгрупу склали 57 \% осіб з менш вираженими ознаками втоми за іншими психофізіологічними показниками. Другу підгрупу осіб склали оператори, які мали достовірно вищі ознаки втоми. В даному дослідженні проведено аналіз характеристик надійності діяльності саме цих груп операторів: підгрупа I - особи з помірною втомою та підгрупа II - 3 сильно вираженими ознаками втоми.

Аналіз «розмаїття», «унікальності» та «спорідненості» різних типів помилок людини здійснювався в трьох діапазонах інформаційного навантаження в залежності від показника ФРНП (до $30 \%$, тобто від ФРНП до ФРНП+0,3×ФРНП - «високе» інформаційне навантаження; від 30 до 60 \% - «низьке» інформаційне навантаження та більше 60 \% ФРНП - «наднизьке» інформаційне навантаження) з урахуванням їх зв'язку з характеристикою відносного зсуву ФРНП

(C) В. В. Кальниш , А. В. Швець 
після добового чергування, що певним чином віддзеркалює рівень розвитку втоми кожного оператора в процесі добового чергування.

Статистичний аналіз результатів проводився за допомогою методів варіаційної та непараметричної (критерій Манна-Уітні) статистики, кластерного та кореляційного аналізу з використанням пакета програм STATISTICA 8.0. та методів структурного аналізу.

Результати власних досліджень та їх обговорення. Якщо розглядати взаємодію людини 3 машиною 3 точки зору структурної лінгвістики, можна вважати, що їх «спілкування» відбувається з допомогою специфічної мови, аналіз якої дасть можливість визначити ті ситуації, які сприяють успішному виконанню роботи чи виникненню помилок. Фрагменти реакцій людини та машини як самостійні одиниці спостереження формують певну структурно-лінгвістичну модель, що може описати надійність роботи оператора. Вибір тих чи інших ділянок представлення інформації про часову послідовність дій пов' язаний 3 гіпотезою про те, як розподілена ця інформація на кривій, що віддзеркалює взаємодію людини з машиною. Тому при здійсненні аналізу даної взаємодії слід провести сепарацію окремих інформативних ділянок, які віддзеркалюють поведінку людини та машини, а також класифікувати їх. Розглядання ефекту появи помилок дало можливість виділити сім типів («літер») помилок (табл. 1).

Таблиця 1. Типи помилкових реакцій

\begin{tabular}{|c|c|}
\hline 1 & відсутність реакції після правильної відповіді на збуджувальний подразник; \\
\hline 2 & відсутність дії після правильної реакції на гальмівний подразник; \\
\hline 3 & помилкова дія після відсутності реакції на збуджувальний сигнал; \\
\hline 4 & повторна відсутність реакції на збуджувальний сигнал; \\
\hline 5 & відсутність дії на збуджувальний сигнал після помилкової реакції на збуджувальний сигнал; \\
\hline 6 & помилкова дія після правильної реакції на гальмівний подразник; \\
\hline 7 & помилкова дія після правильної реакції на збуджувальний подразник \\
\hline
\end{tabular}

У даному випадку доцільно розглянути деякі особливості та закономірності появи «літер», що визначаються помилковими діями оператора у цій «мові». Для проведення такого аналізу були застосовані три характеристики появи помилкових дій: «унікальність» (відображає вірогідність виникнення цієї дії людини в процесі виконання завдання у відповідному діапазоні інформаційного навантаження), «спорідненість» (реально існуюча сукупність помилкових дій оператора, що поєднується їх стійкими зв'язками, утвореними в результаті конкретної діяльності, а також їх взаєминами, які відрізняються відносною цілісністю та мають ряд спільних ознак, що надають їм певну своєрідність), та «розмаїття» (свідчить про те, яка кількість типів помилок присутня в гіпотетичній колекції помилок, де вони усі мають рівномірні частоти при умові, якщо вона має таке ж розмаїття, як дана колекція помилок).

Узагальнюючи інформацію, отриману при аналізі «спорідненості» помилок у осіб з меншим і більшим рівнями втоми потрібно зауважити, що як до чергування (висока працездатність), так і після чергування (розвинута втома) на «спорідненість» багатьох типів помилок впливає темп інформаційного навантаження. «Спорідненість» помилок у представників різних підгруп суттєво вища при «низькому» темпі роботи та зменшується при його підвищенні, особливо при зростанні ознак втоми. Така закономірність, за окремими випадками, не простежується для 4, 5 та 6 типів помилок до початку робочої зміни оператора, проте, з'являється після роботи (розвиток втоми) для 4 та 5 типів помилок. Помилкові дії після правильної реакції на збуджувальний подразник (тип 6) мають високий рівень «спорідненості» як до, так і після роботи. Залежність «спорідненості» від рівня втоми (потенційного) простежується за декількома типами помилок - 1, 2, 3, 5, 6 і сконцентровано в діапазонах, що характеризують надвеликі та дуже низькі рівні інформаційного навантаження (дані отримані до роботи оператора). Тут можна припустити, що оператори, у яких об'єктивно існують різні механізми розвитку втоми, неоднаково будують свій хроноалгоритм діяльності навіть після відпочинку. Цю особливість взаємодії з машиною можна буде застосовувати при розробці заходів щодо завчасного запобігання їх ненадійній роботі.

Ще однією особливістю динаміки «спорідненості» помилок $є$ те, що тільки після зміни, в основному, у дуже втомлених осіб (підгрупа II) стають помітними трансформації «спорідненості» помилок (за типами помилок 4, 6, та 7). Це свідчить про інформативність цих показників до проявів вже розвинутої втоми.

Трансформація показника «унікальності» помилок свідчить про наявність певних закономірностей, які віддзеркалюють процеси переробки інформації оператором. Виявлені суттєві односпрямовані зміни рівня 